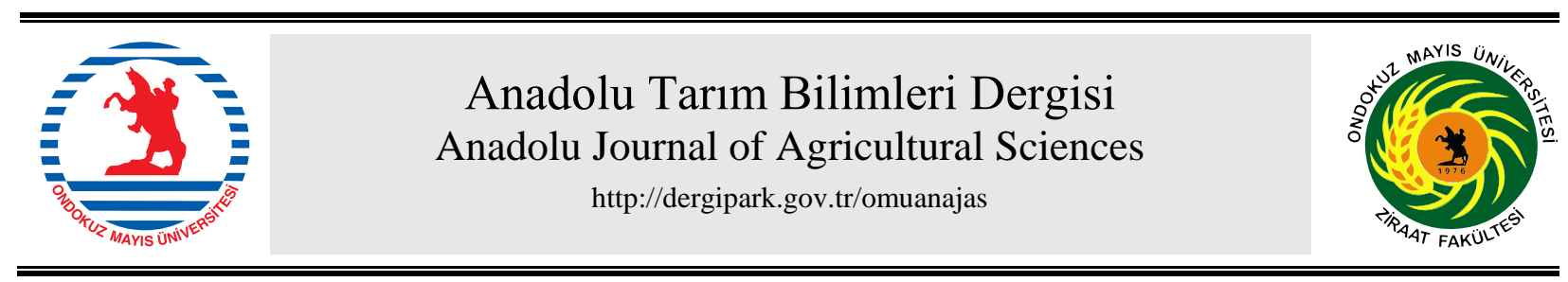

Araştırma/Research

Anadolu Tarım Bilim. Derg./Anadolu J Agr Sci, 36 (2021)

ISSN: 1308-8750 (Print) 1308-8769 (Online)

doi: 10.7161/omuanajas.981203

\title{
Prevalence of Dermanyssus gallinae in Backyard Poultry Houses and Its Relation with Hen-House Conditions in Canakkale, Turkey (1) Coşkun Konyalı ${ }^{\mathrm{a}^{*} \text {, (i) Türker Savaş }}{ }^{\mathrm{b}}$
}

\author{
${ }^{a}$ Lapseki Vocational School, Canakkale Onsekiz Mart University, Canakkale, Turkey \\ ${ }^{\mathrm{b}}$ Department of Animal Science, Faculty of Agriculture, Canakkale Onsekiz Mart University, Canakkale, Turkey
}

*Sorumlu yazar/corresponding author: ckonyali@ comu.edu.tr

Geliş/Received 10/08/2021 Kabul/Accepted 07/09/2021

\begin{abstract}
Poultry red mite (PRM) is most important ectoparasite of poultry due to its harmful effects. This study aims to determine the prevalence of PRM in small free range farms and backyards of poultry breeding and to reveal the correlation between the condition and location of hen-houses with the prevalence of PRM. Analyses were carried out between on August 25th - September 30th in a total of 10 districts and 124 villages in Çanakkale, Turkey. The districts and villages visited in the region were divided into 5 different locations based on their geographical structure and analyses were performed for these locations. In total, 355 coops were surveyed, and the presence of red mite and the conditions of poultry houses were recorded. It was found out that the infestation rate of red mite was $72.39 \%$ in the province of Çanakkale. According to location prevalence, the highest infestation rate was detected in Location 3 $(81.25 \%)$ which is situated in the higher parts of the region. The study observed that the presence of perch, location, air conditioning, height and roof materials of the coops significantly affected the infestation rate $(\mathrm{P}<0.05)$. The probability of incidence of mites was higher in the hen-houses higher than $0.60 \mathrm{~m}$ and with better ventilation and perches. The lowest infestation rate was found in the coops with a galvanized roof, compared to those with the roofs made from tiles, woods or asbestos $(\mathrm{P}<0.05)$. In conclusion, the findings highlighted that geographical and coop conditions should be considered as a point of control for red mites.
\end{abstract}

\section{Türkiye'de Çanakkale'ye Bağlı Köylerdeki Kümeslerde Kanatlı Kırmızı Akarı} Prevalansı ve Kümes Koşulları ile İlişkisi

\section{ÖZET}

Çalışma, 25 Ağustos-30 Eylül tarihleri arasında Çanakkale'ye bağlı 10 ilçe ve 124 köyde gerçekleştirilmiştir. Ziyaret edilen ilçe ve köyler, bölgenin coğrafik yapısına göre 5 farklı lokasyona ayrılarak analizler gerçekleştirilmiştir. Toplam 355 kümes incelenmiş olup, kümeslerdeki Dermanyssus gallinae varlığı tespit edilmiş ve kümes koşullarına ilişkin bilgiler kayıt edilmiştir. Elde edilen bulgulara göre Çanakkale geneline ait akar prevalansının \%72.39 olduğu tespit edilmiştir. Lokasyonlar bazında en yüksek prevalansın \%81.25 ile bölgenin dağlık-yüksek kesimine sahip Lokasyon 3'e ait olduğu görülmektedir. Ele alınan faktörlerden lokasyon, kümes içi havalandırma durumu, tünek varlığı, kümes yüksekliği ve çatı materyalinin akar prevalansı üzerinde istatistiksel olarak önemli etkisinin olduğu tespit edilmiştir $(\mathrm{P}<0.05)$. İyi havalanan, tünek bulunan ve yüksekliği $0.60 \mathrm{~m}$ 'den yüksek olan kümeslerde prevalansın daha yüksek olduğu görülmüştür. Ayrıca çatı malzemesi galvaniz saç olan kümeslerde kiremit, tahta ya da atermit olanlara kıyasla daha az akara rastlanmıştır $(\mathrm{P}<0.05)$. Parazit mücadelesine yönelik yapılan uygulamaların akar prevalansı üzerinde istatistiksel olarak önemli bir etkisinin olmadığı tespit edilmiştir. Sonuç olarak D.gallinae ile mücadelede bölgenin lokasyonu ve kümese bağlı faktörlerin de ele alınması gerektiği görülmektedir.

Keywords:

Dermanyssus gallinae Poultry red mite Prevalence Turkey Infestation Ectoparasite

Anahtar Sözcükler: Dermanyssus gallinae Kanatlı kırmızı akarı Türkiye Enfestasyon Dış parazit

(C) OMU ANAJAS 2021 


\section{Introduction}

Dermanyssus gallinae, poultry red mite (PRM) is a hematophagous and obligatory ectoparasite of domestic and wild birds (McGarry and Trees 1991; Circella et al., 2011; Escobar et al., 2014). It is also known that the red mite attacks mammals including humans (Sikes and Chamberlain, 1954; Duncan 1957; Hoffman 1987; HaagWackernagel, 2008; Bakr et al., 1995; Abd El-Halim et al., 2009). Dermanyssus gallinae is the most important parasite affecting poultry production (Fletcher and Axtell 1991; Maurer and Baumgärtner, 1992). It is reported that the red poultry mite significantly changes the hematological values of the host (Keçeci et al., 2004; Kilpinen et al., 2005; Konyal1, 2016) and at high infestations increases the mortality rate (Arkle et al., 2006; Kaoud et al.; 2010).

The female mites lay eggs at ambient temperatures of $5^{\circ} \mathrm{C}$ to $45^{\circ} \mathrm{C}$, but the optimum conditions for the laying activity are $20^{\circ} \mathrm{C}$, at a humidity of $70 \%$ (Nordenfors et al., 1999). The prevalence of the mite differs greatly according to seasons. In France, it has been reported that Dermanyssus gallinae has a higher prevalence throughout the winter; however, in Denmark and Italy, a higher rate of infestation was noted in the late summer (Beugnet et al., 1997; Chauve 1998; Lubac et al., 2003). It is reported that this parasite, which has rarely been observed in the Netherlands in the past and is usually observed in the summer, is now seen throughout the year (Lesna et al., 2009). A study conducted in Sweden reported that mite intensity increased in the summer compared to the winter months (Nordenfors and Höglund, 2000). It was reported in a study conducted in Iran, that there is a significant correlation between regional climatic conditions and mite prevalence, and the prevalence is higher in the spring (Yakhchali et al., 2013). Studies on the prevalence of red mite are mostly performed in Europe. The infestation rates can reach 80$90 \%$ of poultry as observed in the United Kingdom (UK), Italy, Serbia, Morocco, Japan, Montenegro, and The Netherlands (Sparagano et al., 2009). Except for the report on wild pigeons (Gic1k, 1999), there is no study on red mite prevalence rates in Turkey. There has been currently a very high consumer demand for backyard or free range eggs in Turkey.

The most important point in effectively fighting with PRM is to determine the intensity of in-house density, the points they cluster and the appropriate time to fight against them. The chemicals used unnecessarily and at the wrong time are important for public health and also cause residual in the food of animal origin. Further, mites develop resistance to the acaricides used, which makes the fight against them harder. Revealing the potential correlation between mite intensity and hen-house conditions would probably contribute to the efforts to determine the clustering habits of mites and thus the points where they cluster inside the hen-house.

In this context, this study aims to determine the correlation between PRM prevalence and the conditions of backyards of chicken houses in Çanakkale, Turkey and to reveal the conditions of hen-houses.

\section{Material and Methods}

\subsection{Experiment Site}

This study was conducted between August 25th - September 30th in a total of 124 villages in 10 districts in Çanakkale. The types examined mostly consisted of small backyard chicken houses. In total, 355 poultry houses were analyzed for the presence of red mites. The conditions of the hen-houses were also examined (Table 1). The districts and villages visited in the region were divided into 5 different locations based on their geographical structure. Figure 1 shows the locations on the map. 'Location 1' includes the coastlines of Lapseki, Gelibolu, Eceabat and Center districts. The villages in Biga district situated in the north-east of Canakkale was named 'Location 2'. The parts of the region with a high altitude (Çan, Yenice and a part of Bayramiç districts) were called 'Location 3.' The lowlands of Ezine and a part of Bayramiç were named as 'Location 4'. 'Location 5' covers the villages in Ayvacık district, which is elongated in the south of Çanakkale and the coastline of Aegean Sea.

\subsection{Statistical analysis}

The prevalence in the hen-houses was classified as observed or unobserved. The effects of the discussed factors were analyzed using GEE procedure based on binomial distribution [26]. The statistical model included the conditions of hen-houses (Table 1), location (5 levels), and applied treatment to control of parasite (Yes - No). The effects were assessed in terms of odds ratio, regression coefficients and standard error of regression coefficients. Odds ratio was defined as the ratio of observation to non-observation of the parasite. Odds ratio was calculated from the equation of $\mathrm{c}=\mathrm{eb}$, where $\mathrm{c}$ is the odds ratio, $\mathrm{b}$ is the regression coefficient and $\mathrm{e}$ is the exponential constant. A Wald chi-square statistic was computed for the contrast for the groups of significant effects. 
Table 1. Observed parameters of the hen-houses.

Çizelge 1. Kümeslerde gözlenen parametreler.

\begin{tabular}{|c|c|c|c|c|}
\hline Parameters & \multicolumn{4}{|c|}{ Scale } \\
\hline Ventilation & Good & Poor & & \\
\hline Window & Available & NA & & \\
\hline Floor & Dry & Wet & & \\
\hline Perch & Available & NA & & \\
\hline Height & Short $(<0.6 \mathrm{~m})$ & $\operatorname{Medium}(0.6-1 \mathrm{~m})$ & $\operatorname{High}(>1 \mathrm{~m})$ & \\
\hline Roof Material & Galvanized & Asbertos & Tile & Wood \\
\hline
\end{tabular}

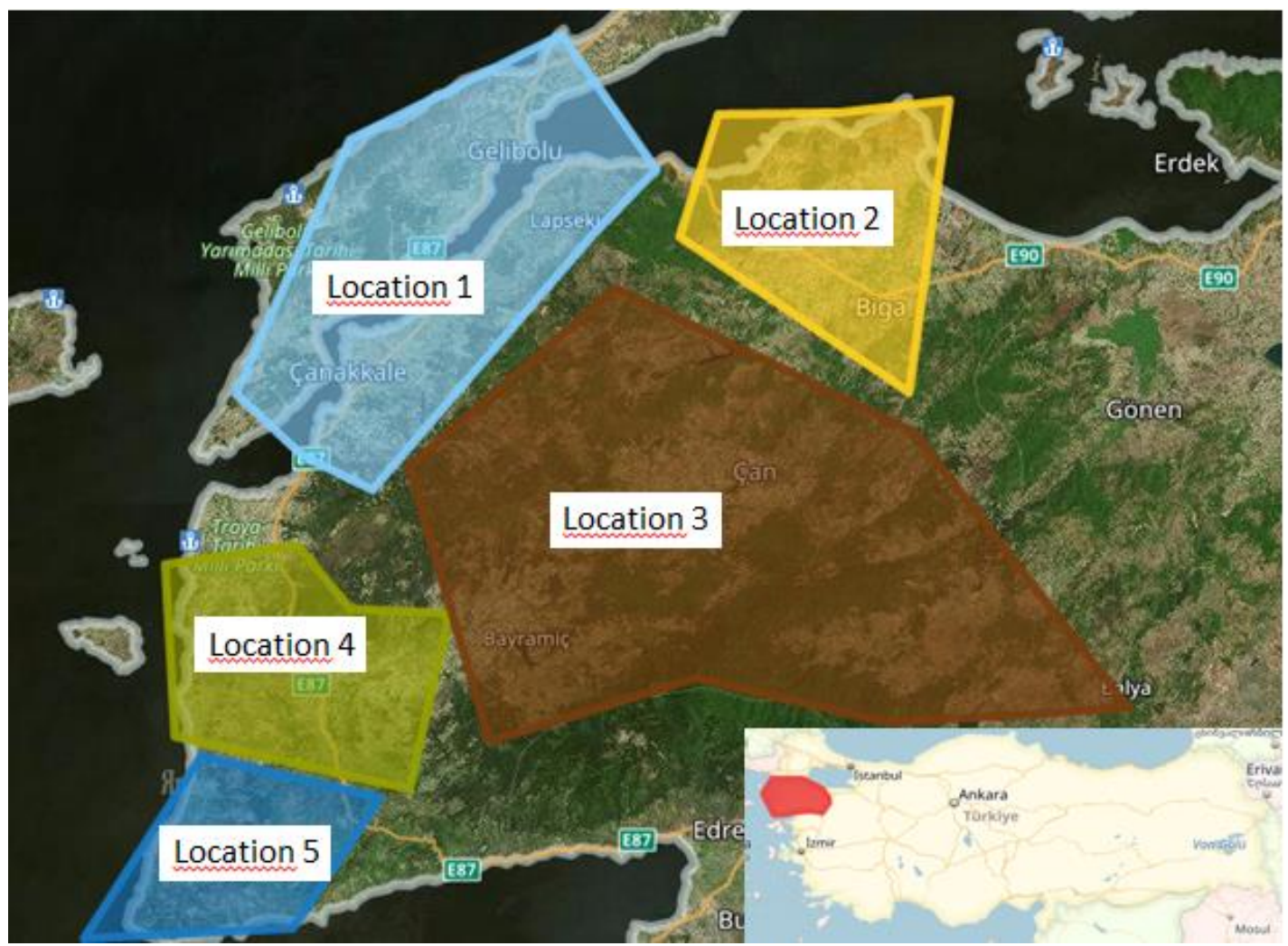

Figure 1. Geographical locations of the villages in which the poultry houses are located.

Şekil 1. Kümeslerin konumunun coğrafik lokasyonlara göre harita üzerine görünümü.

\section{Results and Discussion}

Table 2. contains descriptive information regarding the physical conditions of examined hen-houses and $36.62 \%$ of that hen-houses no had good ventilation conditions. While it is observed that the litter condition is mostly dry $(94.37 \%)$, similarly, there was a material that can serve as perch or perch in almost all of the houses. It was seen that at least one treatment was treated against diseases and parasites in $84.56 \%$ of the hen-houses.

The overall infestation rate of poultry red mites was $72.4 \%$ in Çanakkale Province (Figure 2). According to location prevalence, the highest infestation rate was detected in Location $3(81.3 \%)$, which is situated in the higher parts of the region. On the other hand, the lowest prevalence was found in Location 5 (48.57\%). Location 1 where is located Dardanelles had $76.36 \%$ prevalence.

The results regarding mite density categories by locations is shown in Table 3. Although no mites found in $28.95 \%$ of the hen - houses in the 4th location, $34.21 \%$ of hen - houses were in high mite density (Table 3 ). The location with the highest medium mite density level was in the 3rd location and this location had highest prevalence regarding to medium and high levels of density of mites. The 5th location was the location where mite infestation is the least in terms of both intensity and prevalence. No mites observed in more than half of the hen - houses in the Location 5. 
Table 2. Descriptive information on physical conditions in observed hen - houses

Çizelge 2. İncelenen kümeslerin fiziki koşullarına ilişkin tanımlayıcı bilgiler

\begin{tabular}{c|c|c}
\hline \multirow{2}{*}{ Factors } & Levels & \% \\
\hline \multirow{2}{*}{ Ventilation } & Available & 63.38 \\
& NA & 36.62 \\
\hline \multirow{2}{*}{ Window } & Available & 49.86 \\
& NA & 50.14 \\
\hline \multirow{2}{*}{ Floor } & Wet & 5.63 \\
& Dry & 94.37 \\
\hline \multirow{2}{*}{ Perch } & Available & 92.11 \\
& NA & 7.89 \\
\hline \multirow{2}{*}{ Height } & Short (<0.6 m) & 32.11 \\
& Medium (0.6-1 m) & 34.65 \\
& High $(>1 \mathrm{~m})$ & 33.24 \\
\hline \multirow{2}{*}{ Roof Materials } & Asbestos & 27.75 \\
& Tile & 43.38 \\
& Wood & 6.20 \\
\hline \multirow{2}{*}{ Treatment } & Galvanized & 32.68 \\
\hline
\end{tabular}

\section{Prevalence}

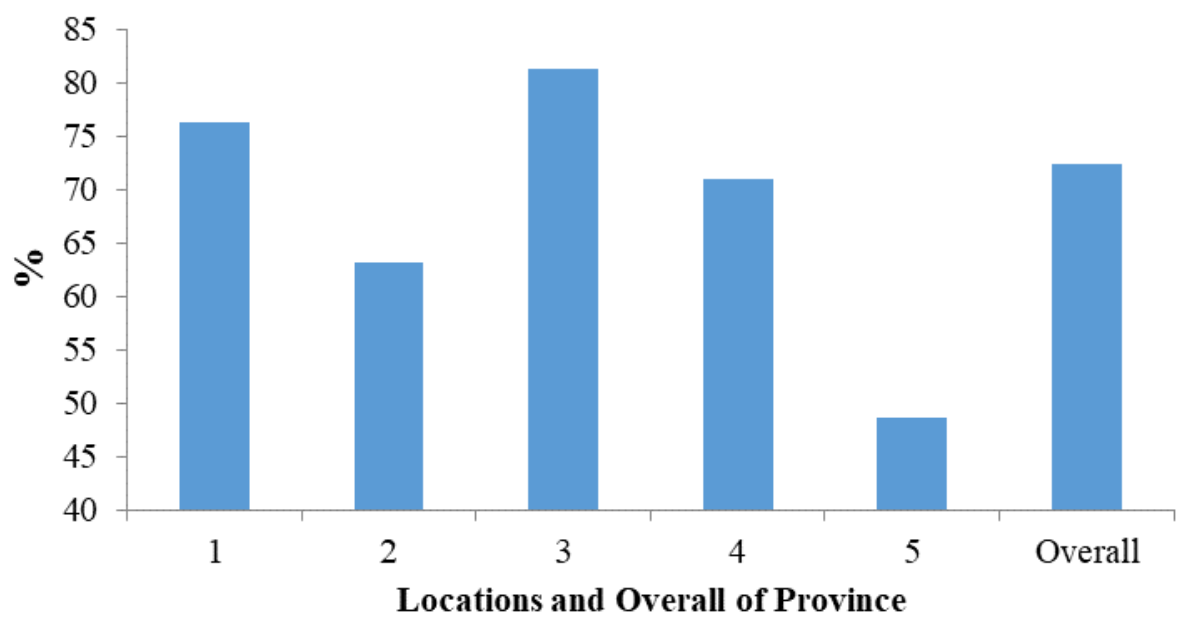

Figure 2.Prevalence of poultry red mites by Location.

Şekil 2. Lokasyona göre kanatlı kırmızı akarı prevalansı. 
All the coops in the districts in Çanakkale, except for the islands, were scanned for mites. A total of 355 freerange or backyard coops were analyzed in the study. The number of the villages visited as part of the study corresponds to $33 \%$ of the total number of the villages in the city center and districts of Çanakkale. PRM was found in $72.4 \%$ of the coops analyzed. According to reports, the prevalence varies between $50 \%$ and $100 \%$ depending on country (Sparagona et al., 2009). A study reported that red mites were found in $0.84 \%$ of 200 wild pigeons collected from 12 centers in the city of Ankara and its surroundings (Gicik, 1999). It was showed that PRM was one of the parasites detected in 12 coops examining a total of 20 coops in the city of Kars, Turkey (Aldemir, 2004).

Table 3. Percentages of mite density categories by Locations $(\%)$

Çizelge 3. Lokasyonlara göre akar yoğunluk kategorilerine ait yüzdeler.

\begin{tabular}{c|c|c|c|c}
\hline Location & None & Low & Medium & High \\
\hline 1 & 23.64 & 12.73 & 33.64 & 30.00 \\
2 & 36.84 & 10.53 & 31.58 & 21.00 \\
3 & 18.75 & 6.25 & 48.96 & 26.04 \\
4 & 28.95 & 3.95 & 32.89 & 34.21 \\
5 & 51.43 & 5.71 & 25.71 & 17.14 \\
Overall & 27.61 & 8.17 & 36.62 & 27.61 \\
\hline
\end{tabular}

The effect of location on prevalence is statistically significant $(P=0.0207$; Table 4$)$. The infestation rate were 5.37 times higher in Location 3 and 3.19 times higher Location 1, compared to Location 5. Location The effects of ventilation of the hen-houses on prevalence was also found significant; the infestation rate in the better-ventilated hen-houses were 12.18 times higher than that of the poorly-ventilated poultry houses $(\mathrm{P}<0.0001)$.

No significant differences were found between windowless and poultry houses with windows $(\mathrm{P}=0.8039)$. Although the prevalence was higher in poultry houses with dry floors, the difference was not significant. $(\mathrm{P}=$ 0.1070). The prevalence in the hen-houses with perches were 4.83 times higher $(P=0.0013)$. The effects of house height were significant on prevalence, and the house heights below $0.6 \mathrm{~m}$ have less infestation $(\mathrm{P}=0.0058)$. Roofing material significantly affected the prevalence of red mites $(P=0.0212)$. The lowest infestation rate was found in galvanized roofing materials $(P=0.0212)$. Any treatment against mites had no effect on the mite prevalence $(\mathrm{P}=0.1584)$.

The prevalence of mites, which shows a seasonal activity like many other types of external parasites, depends on geographical location. In this sense, one of the most critical factors on the prevalence is season. This study was carried out in August and September. Due to its location, Çanakkale has a different climatic structure. There are some regions with dry and very hot summers as well as others with hot and humid or sub-humid summers, receiving light-to-moderate rain. The locations were selected according to these climatological conditions and analyzed. The results showed that the highest rates of infection were in higher regions. These locations were probably more favorable for Dermanyssus gallinae in the months studied. In fact, the temperatures in these locations are lower during these months than other locations. The lowest mite prevalence was in the villages, coops in Biga, which is in the north-east of Çanakkale (Location 1) and in the villages in Ayvacık, which forms the southern part of Çanakkale and is on the coast of the Aegean Sea (Location 3). It is known that Location 1 forms the plain part of Biga, where irrigation-based agriculture and paddy breeding are particularly practiced. This probably leads to high proportional humidity in the region. On the other hand, Location 3 is in the south of Çanakkale, with a very dry and hot summer compared to other locations. PRM, which is probably sensitive to high temperature and humidity, disappears in these locations. Although PRM was not found in these locations, the traces of its clusters including its skin residues and feces residues were observed in the splits and cracks inside the hen-houses. The hen-houses visited in these locations were very sultry because of the in-house climate. However, PRM is reported to have a higher prevalence in France throughout the winter while it has a higher infestation rate in Denmark and Italy at the end of the summer (Beugnet et al., 1997; Chauve 1998; Lubac et al., 2003). It is revealed that this parasite, which was rarely seen in the Netherlands in the past and usually during the summer, is now observed all year round (Lesna et al., 2009). Mite prevalence increases in the summer months compared to the winter months in Sweden (Nordenfors and Höglund, 2000). It is known that prevalence is significantly associated with regional climate locations (Yakhchali et al., 2013). It is reported that the seasonal variance in the number of PRM results from a diapause-like state where the winged red mites enter in the absence of a host or when the temperature falls (Nordenfors and Höglund, 2000). 
Ventilation has an important effect on optimizing the in-house temperature. Given that the study was performed in summer, ventilation appeared to be even more important. It was observed that the coops without ventilation had a hot and sultry climate. With the ambient temperature rising above $35^{\circ} \mathrm{C}$, it is known that PRM mortality increases and reproduction decreases, and population may be destroyed completely (Tucci et al., 2008). Dehydration may be one of the factors effective in reducing the parasites in relation to temperature (Nordenfors et al., 1999). Within the period when the study was performed, the lowest prevalence was reported in the southern part of Çanakkale, which is a dry location dominated by the extreme heat, and in the overheating plain part. The highest mite prevalence was found in the region with a high altitude and warm and rainy summers. High populations of mites were detected in the hen-houses, which were not properly and regularly cleaned, contaminated with feces, on the condition that the litter was dry (Maurer et al., 1993; Sparagano et al., 2009).

Table 4. Regression coefficients (b), standard errors (SE), odds ratios ( $\Psi)$ and $P$ - values of factors discussed on red mite prevalence

Çizelge 4. Kanatlı kırmızı akarı üzerinde etkisi irdelenen özelliklere ait regresyon katsayısı, standart hata, Odds orant ve önem değerleri

\begin{tabular}{|c|c|c|c|c|c|}
\hline Factors & Levels & $b$ & SE & $\Psi$ & $\mathbf{P}$ \\
\hline \multirow{5}{*}{ Location } & 1 & 1.16 & 0.65 & $3.19^{\mathrm{c}}$ & \multirow{5}{*}{0.0207} \\
\hline & 2 & -0.16 & 0.74 & $0.85^{\mathrm{a}}$ & \\
\hline & 3 & 1.68 & 0.68 & $5.37^{\mathrm{c}}$ & \\
\hline & 4 & 1.02 & 0.65 & $2.77^{\mathrm{bc}}$ & \\
\hline & 5 & 0.00 & 0.00 & $1.00^{\mathrm{b}}$ & \\
\hline \multirow{2}{*}{ Ventilation } & Good & 2.50 & 0.58 & 12.18 & \multirow{2}{*}{$<0.0001$} \\
\hline & Poor & 0.00 & 0.00 & 1.00 & \\
\hline \multirow{2}{*}{ Window } & Available & -0.14 & 0.56 & 0.87 & \multirow{2}{*}{0.8039} \\
\hline & $\mathrm{NA}^{*}$ & 0.00 & 0.00 & 1.00 & \\
\hline \multirow{2}{*}{ Floor } & Wet & -1.36 & 0.88 & 0.26 & \multirow{2}{*}{0.1070} \\
\hline & Dry & 0.00 & 0.00 & 1.00 & \\
\hline \multirow{2}{*}{ Perch } & Available & 1.57 & 0.69 & 4.83 & \multirow{2}{*}{0.0013} \\
\hline & NA & 0.00 & 0.00 & 1.00 & \\
\hline \multirow{3}{*}{ Height } & Short & 0.60 & 0.56 & $1.82^{\mathrm{a}}$ & \multirow{3}{*}{0.0058} \\
\hline & Medium & 1.64 & 0.57 & $5.14^{\mathrm{b}}$ & \\
\hline & High & 0.00 & 0.00 & $1.00^{\mathrm{a}}$ & \\
\hline \multirow{4}{*}{ Roof Materials } & Asbestos & 1.12 & 0.56 & $3.06^{\mathrm{b}}$ & \multirow{4}{*}{0.0212} \\
\hline & Tile & 1.30 & 0.48 & $3.68^{\mathrm{b}}$ & \\
\hline & Wood & 1.47 & 0.89 & $4.31^{\mathrm{b}}$ & \\
\hline & Galvanized & 0.00 & 0.00 & $1.00^{\mathrm{a}}$ & \\
\hline \multirow{2}{*}{ Treatment } & Yes & 0.68 & 0.48 & 1.97 & \multirow{2}{*}{0.1584} \\
\hline & No & 0.00 & 0.00 & 1.00 & \\
\hline
\end{tabular}

\section{*NA: Non available}

The hen-houses with perches showed higher prevalence levels $(\mathrm{P}=0.0013)$. The perches provide suitable places for the mites to hide and nest and thus the mites can survive longer in these houses. Further, the parasites stored in the perches can easily reach the host. The houses with a roof height lower than $0.6 \mathrm{~m}$ had less infestation. The higher houses had a greater volume, which probably improves the air quality. The roofing material of the poultry houses significantly affected the prevalence of red mites. The lowest infestation rate was detected in the galvanized roofing materials. Galvanized material heats up more than other roofing materials and dissipates the heat into the room below. The poultry houses with galvanized roofs are potentially warmer than the poultry houses with a roof made with other materials. Therefore, the roofing of the houses made with galvanized materials would have less prevalence. As the houses with a wooden roof have better ventilation and these houses are relatively cooler than 
other houses, the prevalence of the mites were higher. On the other hand, the materials such as tile and thermite do not heat the inside of the houses as much as the galvanized sheet does.

No statistically important effect of parasite administration on the prevalence was detected $(\mathrm{P}=0.1584)$. On the contrary, the probability of incidence of mites was found to be numerically higher in the hen-houses where a parasite administration was performed. The analyses demonstrated that the fight for parasites is unconsciously and uncontrollably carried out. The most remarkable finding was that the breeders do not know the first thing about mites and the fight against them. The incorrect use of pesticides and active substances, incorrect dose, frequency of use and application lead to ineffective fights against mites. Moreover, it is known that mites develop resistance to the chemicals used for fighting against them (Sparagano et al., 2014) and reduce the effectiveness of acaricides used.

\section{Conclusion}

This first report from Turkey on the prevalence of Dermanyssus gallinae in backyards has shown that red mite is a serious problem. In general, it was observed that infestation rate increases with improved coop conditions. The prevalence was better in the higher and well-ventilated hen-houses. It was further found that the probability of incidence of mites was higher in the hen-houses higher than $0.60 \mathrm{~m}$ and with better ventilation and roof insulation, regardless of the hygiene of the hen-houses. This points out that having "favorable" conditions in hen-houses for breeding also means having favorable conditions for mite reproduction. Furthermore, the prevalence possibly varied by location, and the parameters discussed are closely related to the hen-houses conditions. It should be noted these results are valid for the period studied and further studies should be performed throughout an entire year. The knowledge on the relation of hen-house conditions to survival during specific abiotic conditions provides useful information for the understanding of their population dynamics.

\section{References}

Abd El-Halim, A.S., Allam, K.A., Metwally, A.M., El Boraey, A.M., 2009. Seasonal variation of infestation rate with lice, tick and mite among rodents in certain Egyptian regions. Journal of the Egyptian Society of Parasitology 2009; 39(2):617-24. PMID: 19795768.

Aldemir, O.S., 2004. Ectoparasites in Chickens in the Province of Kars. Türkiye Parazitoloji Dergisi 2004; 28 (3): 154-157.

Arkle, S., Guy, J.H., Sparagano, O., 2006. Immunological effects and productivity variation of red mite (Dermanyssus gallinae) on laying hens- implications for egg production and quality. World's Poultry Science Journal 2006; 62 (2): 249-257. doi: https://doi.org/10.1079/WPS200594.

Bakr, M.E., Morsy, T.A., Nassef, N.E., el Meligi, M.A., 1995. Mites infesting commensal rodents in Shebin El Kom, Menoufia G., Egypt. Journal of the Egyptian Society of Parasitology 1995; 25(3):853-9. PMID: 8586878.

Beugnet, F., Chauve, C., Gauthey, M., Beert, L., 1997. Resistance of the red poultry mite to pyrethroids in France. Veterinary Record 1997; 31;140 (22) :577-9. doi: 10.1136/vr.140.22.577. PMID: 9194299.

Chauve, C., 1998. The poultry red mite Dermanyssus gallinae (De Geer, 1778): current situation and future prospects for control. Veterinary Parasitology 1998; 16;79 (3) :239-45. doi: 10.1016/s0304-4017(98)00167-8. PMID: 9823064.

Circella, E., Pugliese, N., Todisco, G., Cafiero, M.A., Sparagano, O.A., Camarda, A., 2011. Chlamydia psittaci infection in canaries heavily infested by Dermanyssus gallinae. Experimental and Applied Acarology 2011; 55(4):329-38. doi: 10.1007/s10493-011-9478-9. Epub 2011 Jul 15. PMID: 21761223.

Duncan, S., 1957. Dermanyssus gallinae (De Geer, 1778) attacking man. Journal of Parasitology 1957; 43:637.

Escobar, C.M.A., Pérez-Lara, E., Garcíalópez, J.C., Arroyo-Ledezma, J., Sánchez-Bernal, E.I., 2014. Parasitic Mites in Backyard Turkeys In Oaxaca's Coast, Mexico. Tropical and Subtropical Agroecosystems 2014; 12: 675 679.

Fletcher, M.G., Axtell, R.C., 1991. Susceptibility of northern fowl mite, Ornithonyssus sylviarum (Acarina:Macronyssidae), and chicken mite, Dermanyssus gallinae (Acarina: Dermanyssidae) to selected acaricides. Experimental and Applied Acarology 1991; 13:137-142. doi:10.1007/BF01193664.

Gıcık, Y., 1999. Ankara ve Çevresinde Yaban Güvercinlerde Ektoparazitler. Kafkas Universitesi Veteriner Fakultesi Dergisi 1999; 5 (1): 71-74.

Haag-Wackernagel, D., 2008. Gesundheitsgefährdungen durch die Straßentaube Columba livia: Parasiten. Amtstierärztlicher Dienst und Lebensmittelkontrolle 2008; 15:174-188.

Hoffman, G.V., 1987. Vogelmilben als Lästlinge, Krankenheitsserzeuger und Vektoren bei Mensch und Nutztier. Deutsche Tierärztliche Wochenschrift 1987; 95: 7-10. 
Kaoud, H.A., El-Dashan, A.R., 2010. Effect of Red Mite (Dermanyssus gallinae) Infestation on the Performance and Immun Response in Broiler Breeder Flocks. Journal of American Science 2010; 6 (8) : 72-79.

Keçeci, T., Handemir, E., Orhan, G., 2004. Dermanyssus gallinae infestasyonunun horozların bazı hematolojik değerleri ve canlı ağırlıkları üzerine etkisi. Türkiye Parazitoloji Dergisi 2004; 28 (4) : 192 - 196.

Kilpinen, O., Roepstorff, A., Permin, A., Nørgaard-Nielsen, G., Lawson, L.G., Simonsen, H.B., 2005. Influence of Dermanyssus gallinae and Ascaridia galli infections on behaviour and health of laying hens (Gallus gallus domesticus). British Poultry Science 2005; Feb;46 (1) :26-34. doi: 10.1080/00071660400023839. PMID: 15835249.

Konyal1, C., Erdem, H., Eralp, E., Savaş, T., 2018. Inseparable Duo: Dermanyssus gallinae and Its Birds. Scientia Parasitologica 2018; 19: Special issue, 48-48.

Lesna, I., Wolfs, P., Faraji, F., Roy, L., Komdeur, J. Sabelis, M.W., 2009. Candidate predators for biological control of the poultry red mite Dermanyssus gallinae. Experimental and Applied Acarology 2009; 48 (1-2):63-80. doi: 10.1007/s10493-009-9239-1. Epub 2009 Jan 30. PMID: 19184469.

Lubac, S., Dernburg, A., Bon, G., Chauve, C., Zenner, L., 2003. Problématique Et Pratiques D’élevages En Poules Pondeuses Dans Le Sud Est De La France Contre Les Nuisibles: Poux Rouges Et Mouches. In: ITAVI, INRA, AFSSA (eds) 5emes journées de la recherche avicole 2003; pp 101-104.

Maurer, V., Baumgärtner, J., 1992. Temperature influence on life table statistics of the chicken mite Dermanyssus gallinae (Acari: Dermanyssidae). Experimental and Applied Acarology 1992; 15(1):27-40. doi: 10.1007/BF01193965. PMID: 1511637.

Maurer, V., Fösch, D.W., Baumgärtner, J., 1993. Untersuchung der Populationsdynamik der Roten Vogelmilbe im Hinblick auf die Entwicklung von nachaltigen Bekämpfungsmethoden. Landwirtschaft Schweitz 1993; 6:475480.

McGarry, J.W., Trees, A.J., 1991. Trap perches to assess the activity of pyrethrins against the poultry red mite Dermanyssus gallinae in cage birds. Experimental and Applied Acarology 1991; 12(1-2):1-7. doi: 10.1007/BF01204395. PMID: 1748030.

Nordenfors, H., Höglund, J., Uggla, A., 1999. Effects of temperature and humidity on oviposition, molting, and longevity of Dermanyssus gallinae (Acari: Dermanyssidae). Journal of Medical Entomology 1999; 36 (1) :6872. doi: 10.1093/jmedent/36.1.68. PMID: 10071495 .

Nordenfors, H., Höglund, J., 2000. Long term dynamics of Dermanyssus gallinae in relation to mite control measures in aviary systems for layers. British Poultry Science 2000; 41 (5):533-40. doi: 10.1080/713654991. PMID: 11201430.

SAS Institute Inc., 2002. User's Guide. Version 6.07, Cary, NC, USA.

Sikes, R.K., Chamberlain, R.W., 1954. Laboratory observations on three species of bird mites. Journal of Parasitology 1954; 40(6): 691-7. PMID: 13212549.

Sparagano, O., Pavlićević, A., Murano, T., Camarda, A., Sahibi, H., Kilpinen, O., Mul, M., Van Emous, R.,

Sparagano, O.A., George, D.R., Harrington, D.W., Giangaspero, A., 2014. Significance and control of the poultry red mite, Dermanyssus gallinae. Annual Review of Entomology 2014; 59:447-66. doi: 10.1146/annurev-ento011613-162101. PMID: 24397522.

Tucci, E.C., Prado, A.P., Araújo, R.P., 2008. Development of Dermanyssus gallinae (Acari: Dermanyssidae) at different temperatures. Veterinary Parasitology 2008; 1;155(1-2):127-32. doi: 10.1016/j.vetpar.2008.04.005.

Yakhchali, M., Rasouli, S., Alborzi, E., 2013. Prevalence and body distribution of the poultry red mite in layer farms from Markazi province of Iran. Iranian Journal of Veterinary Research 2013; 14 (1), 72-74. doi: 10.22099/ijvr.2013.1394. 